\title{
Comparative Analysis Of Owner Managed And Lease Managed System Of Cocoa Production In Ekiti State Nigeria.
}

\author{
Sekumade A. B. \\ Department of Agricultural Economics and Extension Services Faculty of Agricultural Sciences, Ekiti State \\ University Ado-Ekiti, Nigeria.
}

\begin{abstract}
This paper examines the comparative study of Owner managed and Lease managed system of cocoa production in Ekiti state, Nigeria. Through a multistage sampling technique, one hundred and twenty (120) respondents were interviewed and data collected with the aid of a well structured questionnaire. Data were analysed with Descriptive Statistics, Probit Regression Analysis and Budgetary techniques. The respondents are basically farmers with high involvement in cocoa plantation. The result of the descriptive statistic shows that majority of the respondents are Male (90.2\%) while 9.8\% of the respondents are Female, the respondents are between the age of $20-82$ years with a mean age of 56 years, $90.8 \%$ of the respondents are married while only $9.2 \%$ are single, the average household size is 7 . About $43 \%$ have no formal education. The average farm holding is 3 hectare which signifies that majority of the respondents operates at the subsistence level. Majority of the respondents (55.8\%) used family labour. The average farming experience of the respondents is 17 years, and most of the respondents (54.1\%) make use of personal savings as their source of capital .

The fixed cost and the operating cost are significant at 10\% and 5\% level of significant respectively, this significance however differentiate the two management systems adopted. Gross Margin (GM) for Owner and Lease managed system of production are $\$ 132,890.80$ and $\$ 106,533.35$ respectively, the Economic Efficiency (EE) which is also known as the Rate of Return (ROR) for Owner and Lease managed are 0.55 and 0.63 , the Benefit Cost Ratio (BCR) for Owner and Lease managed are 2.19 and 1.85 respectively indicating that the two management system are efficient and profitable since the BCR is greater than 1 and the Gross Ratio (GR) for Owner and Lease managed system of cocoa production are 0.46 and 1.85 respectively.

Keywords: Cocoa Production, Ekiti State, Lease Managed, Owner Managed.
\end{abstract}

\section{Introduction}

Cocoa gained prominence rapidly in Nigeria in 1965 and then Nigeria became the second largest producer of cocoa in the world. In 1994, cocoa production statistic showed that Nigeria was sixth largest cocoa producer with 135,000 tonnes. The decline in cocoa production involved by farming households was attributed to the discovery and exploitation of petroleum, over independence on oil production at the expense of cash crop production and lack of incentives. Nigeria has over emphasized the exploitation of crude oil as a main source of foreign exchange and employment earnings. The country thus neglected cocoa a versatile, renewable, and sustainable avenue for generating foreign exchange and employment. Among other factors responsible for the declining production of cocoa in south-western Nigeria is the vacuum created by the abolition of the Nigeria cocoa marketing board, old age of the farmers, massive migration from rural areas to urban centres, scarcity and high cost of agricultural labour, incidence of pests and diseases, lack of credit facility to cocoa farmers and indiscriminate bush burning that affect cocoa plantation (CDU, 2003; CRIN, 2003).

The contribution of cocoa to the nation's economic development is vast and have been reported by many authors; in terms of foreign exchange earnings, no single agricultural export commodity has earned more than cocoa, with respect to employment, the cocoa sub-sector still offers quite a sizeable number of people employed both directly and indirectly, it is a source of raw materials to the industries income to farmers, and revenue to the Government of cocoa producing states, (Nkang et al 2006). Cocoa is a concentrated food with high nutritive value, it provides carbohydrate, protein, fat and minerals, it is usually used for making beverages, wine, chocolate, cream and livestock feeds, (Oladosu and Sanusi 2004). Because of its importance, the recent Federal Governments concern of diversifying the export base of the nation has placed cocoa in the centre stage as the most important exporting tree crops. Evidence has however shown that the growth rate of cocoa production has been declining which has given rise to fall in fortunes of the sub-sector among other reasons. Folayan, Daramola and Oguntade (2006), noted that cocoa production in Nigeria witnessed a downward trend after 1971 season, when its export declines to 216,000 metric tons in 1976 and 150,000metric tons in 1986 therefore, reducing the country's market share to about $6 \%$ and to $5^{\text {th }}$ largest producer to date.

Prior to the structural Adjustment programme (SAP) in 1986, Cocoa marketing was carried out by erstwhile highly regulated commodity Marketing Board which were known to pay farmers for less than the export price of cocoa. This situation affected cocoa production and export price of cocoa in the past as it serves 
as a disincentive to investment in cocoa production. Even after the abolition of the Marketing Board Structure, cocoa production has still not fared better as in evidence in declining production trend reported. One of the possible reason may be the nature of investment in cocoa production, as some worry has been expressed as to whether the return from cocoa are not been threatened by such factors as: (i) Rising price of production (ii) Price instability (iii) Declining productivity due to ageing of trees and (iv) Difference in management system. In 1986, the government of Nigeria announced the adoption and implementation of a Structural Adjustment Programme (SAP) with four cardinal objectives as follows: (i) Restructuring and diversifying the productive base of the economy in order to reduce oil exports; (ii) Reducing the dominance of unproductive investment in the public sector; (iii) Encouraging non-oil exports especially agricultural ones; and (iv) Improving the sectors' efficiency and intensify the growth potential of the private sector. The SAP embraced exchange rate deregulation, liberalization of export trade, reduction in extra budgetary expenditure, withdrawal of subsidies and the privatization of public enterprises. Thus, deregulation placed much emphasis on the market forces in determining the prices of goods and services and allocating the resources within the economy.

The fall in percentage share of cocoa output may be attributable to two reasons. First is the negligence of the Agricultural sector by the past administrations due to the discovery of petroleum resources that now accounts for the enormity of foreign exchange and second is the endemic problem in the cocoa industry such as rising cost of production, price instability, and differences in management system. It therefore becomes necessary to examine the relationship that exist between productivity and the type of management system and examine the Economic Efficiency among the two management systems of cocoa in the study area

\section{THE STUDY AREA}

\section{Methodology}

This study was carried out in Ekiti State Nigeria. Ekiti State was created on the $1^{\text {st }}$ of October 1996 which was carved out of the old ondo State with the capital city in Ado Ekiti. Ekiti State is bounded in the North by Kwara State and Kogi State, in the East by Ondo and in the West by Osun State. The State lies between $7^{0} 12^{00}$ and $8^{0} 6^{00}$ North of the equator and longitude $4^{0} 60^{00}$ East. The total land area of the State is about $5804.60 \mathrm{~km}$ with population density of 280 people per square $\mathrm{km}$ according to 1991 population census. The area used for Agricultural purpose is 1.73 million km, 700,000 hectares and 2,700 square miles.

The annual average rainfall ranges between $120 \mathrm{~mm}-180 \mathrm{~mm}$. The temperature ranges from $20^{\circ} \mathrm{c}-27^{0} \mathrm{c}$. The rains are steady and spread almost evenly throughout the wet season which starts around March and ends in October. The state is an agrarian society with farmers in the State involving both in subsistence and the commercial agriculture. Ekiti is chosen as the study area because of its inclination to farming activities and one of the cocoa producing State in Nigeria.

\section{SAMPLING PROCEDURE}

A multi-stage sampling method was used in the selection of respondents in the study area. Three Local Government Areas renowned to be the largest cocoa producing areas in the state were chosen which are: Irepodun Ifelodun Local Government Area, Ise-Orun Local Government Area and Amure Local Government Area. Five towns/villages were randomly selected from each of the Local Government Area and eight farmers were selected from each of the town/village giving both Management System equal chances for the sample collection making a total of 120 farmers in the study area.

\section{ANALYTICAL TOOLS \\ - DESCRIPTIVE STATISTICAL ANALYSIS}

Descriptive statistics was used to discuss the socio-economic characteristics and the factors that affect cocoa production in the study area; they are the mean table, frequency count distribution and the percentage.

\section{-PROBIT REGRESSION ANALYSIS}

Probit Regression Analysis was used to determine the relationship that exists between the management system and their productivity. The Probit Regression Analysis formula is explicitly stated as:

$\mathrm{Y}=\beta_{0}+\beta_{1} X_{\mathrm{n}}+\mathrm{Q}_{\mathrm{i}}$

Where $\mathrm{Y}=$ Depending variables

$\beta_{0}=$ intercept coefficient

$\beta_{1}=$ slope coefficient

$\mathrm{X}_{\mathrm{n}}=$ in-depending variables

$\mathrm{Q}_{\mathrm{i}}=$ error term

$\mathrm{Y}=$ Management system $(1=$ leasehold, $0=$ owner managed $)$

$\mathrm{X}_{1}=$ Fixed cost......( $\left.\mathrm{N}\right)$

$\mathrm{X}_{2}=$ operating cost......( $\left.\mathrm{N}\right)$

$\mathrm{X}_{3}=$ Generated revenue......(N) 
$\mathrm{X}_{4}=$ Yield

$\mathrm{X}_{5}=$ Price

\section{-BUDGETARY TECHNIQUES}

Budgetary Techniques was used to access the Cost and Return implication of the various management system practiced in the study area. The gross margin formula is explicitly stated as:

G.M. $=\sum($ PijQij-rijXij)

Where, Pij = Price of cocoa in ith management system for $\mathrm{jth}$ respondent Qij = quantity of cocoa produced $(\mathrm{kg})$ in ith management system for jth respondent

$\mathrm{Rij}=$ price of variable inputs in ith management system for jth respondent

$\mathrm{Xij}=$ quantity of variable inputs in ith management system for $\mathrm{jth}$ respondent

$\mathrm{I}=1$

$\mathrm{J}=1$ m i.e management system

$\mathrm{M}=$ type of management system

$\mathrm{N}=$ total number of respondents

G.M. = gross margin $(\mathrm{N} / \mathrm{kg})$

$\mathrm{P}=$ average price of cocoa produced $(\mathrm{Ng} / \mathrm{kg}$

$\mathrm{Q}=$ average quantity of cocoa produced $(\mathrm{kg})$

$\mathrm{R} 1$ = purchase price of fertilizer

$\mathrm{R} 2=$ purchase price of insecticide

$\mathrm{R} 3=$ purchase price of herbicide

$\mathrm{R} 4=$ price of transportation

$\mathrm{R} 5$ = price of tree replanting $(\mathrm{N})$

$\mathrm{R} 6$ = price of labour used during production ( $\mathrm{N} / \mathrm{man}$-day)

$\mathrm{X} 1$ = quantity of cocoa produced $(\mathrm{kg})$

$\mathrm{X} 2$ = quantity of fertilizer used (N/hectare)

$\mathrm{X} 3$ = quantity of insecticide used $(\mathrm{N} /$ hectare $)$

$\mathrm{X} 4$ = quantity of cocoa transported

$\mathrm{X} 5$ =quantity of tree replant

X6 = number of hired labour (man-day/hectare)

ECONOMIC EFFICIENCY (EE)

The economic efficiency (EE) is also known as the rate of return (ROR), it is expressed as;

$\mathrm{EE}=\mathrm{NFI} / \mathrm{TC}$

But NFI $=$ TVC - TFC

Where NFI $=$ Net Farm Income and

$\mathrm{TC}=$ Total Cost

$\mathrm{TVC}=$ Total variable cost

$\mathrm{TFC}=$ Total fixed cost .

-THE BENEFIT COST RATIO (BCR)

The benefit cost ratio is expressed as:

$\mathrm{BCR}=\mathrm{TR} / \mathrm{TC}$

Where $\mathrm{TR}=$ total revenue

$\mathrm{TC}=$ total cost

-THE GROSS RATIO (GR)

The gross ratio is expressed as

$\mathrm{GR}=\mathrm{TC} / \mathrm{TR}$

\section{Results And Discussion}

Table 1shows that, very few of the respondents $(15 \%)$ are below 40 years of age and the average age of the respondents is 55.56 years showing that the respondents are relatively old and not in their productive age, the minimum age is 20 while the maximum age is 82 . The gender distribution of the respondent in the study area shows that majority of the respondent are male constituting $90.8 \%$. This shows that more male are involved in cocoa production than the female, this could be as a result of the tedious nature of cocoa farming. It was observed that $90.8 \%$ of the respondents are married while only $9.2 \%$ are single, this could mean a higher assess to family labour rather than hired labour. The educational status of the respondents in the study area shows that 
$42.5 \%$ of the respondents have no formal education, $27.5 \%$ of the respondents had primary education, $25 \%$ of the respondents had secondary education and $5 \%$ of the respondents had tertiary education. This shows that majority of the sample cocoa farmers have education below the secondary level which might affect the ease of technology adoption among the cocoa farm. The average household size of the respondents is 7.95 , this shows a fairly large size. The minimum household number is 1 while the maximum household number is 21 . This could mean an easy access to family labour. $55.8 \%$ of the respondents used family labour, $15 \%$ of the respondents used hired labour and $29.2 \%$ of the respondents used both family and hired labour. Majority of the respondents used family labour, this could be as a result of its availability. It was revealed that $35.8 \%$ of the respondents have farming experience of between $1-10,40 \%$ of the respondents has a farming experience of between $11-$ 20 years, the average years of cocoa farmers experience is 17.66 meaning that the cocoa farmers are experienced. The minimum year of farming experience is 1 while the maximum year is 54 . Moreover, majority (54.1\%) of the respondent's source of capital is personal saving. $71.7 \%$ of the respondents do not belong to any cooperative society while only $28.3 \%$ of the respondents belong to cooperative society. It can be inferred that most of the farmers do not have access to loan. Finally, majority of the respondents (86.7\%) have small size of farm holding which could make mechanisation difficult.

Table 2 shows the factors that affect cocoa production in the study area. Climate change (46.7\%) was the most felt factor that affect cocoa production. $20 \%$ of the respondents suggested that diseases and pest infestation was a threat. $12.5 \%$ of the respondents complained about poor marketing, $8.3 \%$ of the respondents opined that high cost of inputs was a problem, while $12.5 \%$ of the respondents lamented about non-availability of labour.

Table 3 shows the probit regression analysis result for the relationship that exist between the productivity of the cocoa farmers and the type of management system used. The negative coefficient value of the fixed cost implies that lesser fixed cost is incurred among cocoa farmers that uses leasehold management system, while more fixed cost is incurred by owner managed cocoa farmers. The negative coefficient of generated revenue implies that cocoa farmers that used leasehold system generates lower revenue unlike the owner managed cocoa farmers. The negative coefficient of price shows that leasehold management system attracts lower price unlike owner managed system. The positive coefficient of operating cost and yield signifies that cocoa farmers that used leasehold management system incurred more operating cost and consequently have higher yield unlike the owner managed system. The fixed cost and operating cost were significant at $10 \%$ and $5 \%$ level respectively. These significance however differentiate the management system (owner managed and lease managed) adopted by cocoa farmers in Ekiti State Nigeria.

Table 4 shows the budgetary analysis for the two system of cocoa management. The Gross Margin for Owner managed system and Lease managed system of cocoa production are $\$ 132,890.80$ and $\$ 106,533.35$ respectively. This indicates that both management System of cocoa production in Ekiti State, are profitable. The Benefit Cost Ratio (BCR) is one of the concepts of discounted method of project evaluation. As a rule of thumb , Benefit Cost Ratio greater than one indicate profit, equal to one indicate break-even and less than one indicate loss. Since the ratio is greater than one in both management systems ( 2.19 and 1.85 respectively), these shows profit and indicates that both management system of cocoa production in the study area are profitable even with little capital invested into it, It is possible to have higher value of BCR with increase capital and skilled labour.

The Economic Efficiency which is also the Rate of Returns (ROR) for Owner Managed and Lease Managed System of Cocoa Production in Ekiti State are 0.55 and 0.63 respectively. This show that for every N1.00 invested, 55 kobo was gained by Owner Managed farmers and 63 kobo was gained by the farmers using Leasehold in the study area.

The Gross Ratio for Owner Managed and Leased Managed are 0.46 and 0.54 respectively. This implies that for every 1 return to either of the Management system, 46 was spent on Owner Managed system and \$55 was spent on Lease Managed system in the study area.

TABLE 1: SOCIO-ECONOMIC CHARACTERISTICS OF THE RESPONDENTS

\begin{tabular}{|l|l|l|l|}
\hline VARIABLES & CATEGORY & FREQUENCY & PERCENTAGE \\
\hline Age (years) & Below 40 & 18 & 15 \\
\hline & $40-49$ & 20 & 16.7 \\
\hline & $50-59$ & 32 & 26.7 \\
\hline & $60-69$ & 25 & 20.8 \\
\hline Total & 70 and above & 25 & 20.8 \\
\hline Gender & - & 120 & 100 \\
\hline & Male & 109 & 90.8 \\
\hline Total & Female & 11 & 9.2 \\
\hline Marital Status & - & 120 & 100 \\
\hline & Single & 11 & 9.2 \\
\hline Total & Married & 109 & 90.8 \\
\hline Level of Education & - & 120 & 100 \\
\hline & No Formal Education & 51 & 42.5 \\
\hline
\end{tabular}


A Comparative Analysis Of Owner Managed And Lease Managed System Of Cocoa Production In

\begin{tabular}{|c|c|c|c|}
\hline & Secondary Education & 30 & 25 \\
\hline & Tertiary Education & 6 & 5 \\
\hline Total & - & 120 & 100 \\
\hline \multirow[t]{4}{*}{ Household Size } & $1-5$ & 35 & 29.2 \\
\hline & $6-10$ & 58 & 48.3 \\
\hline & $11-15$ & 24 & 20 \\
\hline & $>15$ & 3 & 2.5 \\
\hline Total & - & 120 & 100 \\
\hline \multirow[t]{3}{*}{ Labour } & Family & 67 & 55.8 \\
\hline & Hired & 18 & 15 \\
\hline & Both & 35 & 29.2 \\
\hline Total & - & 120 & 100 \\
\hline \multirow{5}{*}{$\begin{array}{l}\text { Farming Experience } \\
\text { (years) }\end{array}$} & $1-10$ & 43 & 35.8 \\
\hline & $11-20$ & 48 & 40 \\
\hline & $21-30$ & 9 & 7.5 \\
\hline & $31-40$ & 10 & 8.3 \\
\hline & $>40$ & 10 & 8.3 \\
\hline Total & - & 120 & 100 \\
\hline \multirow[t]{5}{*}{ Source of Capital } & Personal Savings & 65 & 54.1 \\
\hline & Cooperative Society & 5 & 4.2 \\
\hline & Bank & 4 & 3.3 \\
\hline & Friends and Relatives & 17 & 14.2 \\
\hline & Money Lenders & 29 & 24.2 \\
\hline Total & - & 120 & 100 \\
\hline \multirow{2}{*}{$\begin{array}{l}\text { Membership of } \\
\text { Cooperative Society }\end{array}$} & No & 86 & 71.7 \\
\hline & Yes & 34 & 28.9 \\
\hline Total & - & 120 & 100 \\
\hline \multirow[t]{4}{*}{ Farm Size (hectares) } & $<1$ & 23 & 19.2 \\
\hline & $1-3$ & 81 & 67.5 \\
\hline & $4-6$ & 11 & \\
\hline & $>6$ & 5 & \\
\hline Total & - & 120 & 100 \\
\hline
\end{tabular}

Source: Field Survey, 2013.

TABLE2: FACTORS THAT AFFECT COCOA PRODUCTION IN THE STUDY AREA

\begin{tabular}{|l|l|l|}
\hline FACTOR & RREQUENCY & PERCENTAGE \\
\hline Climatic change & 56 & 46.7 \\
\hline Pest and Disease Infestation & 24 & 20 \\
\hline Marketing factor & 15 & 12.5 \\
\hline High cost of Inputs & 10 & 8.3 \\
\hline Unavailability of Labour & 15 & 12.5 \\
\hline Total & 120 & 100 \\
\hline
\end{tabular}

Source: Field Survey, 2013.

TABLE 3: THE RELATIONSHIP BETWEEN THE PRODUCTIVITY OF THE COCOA FARMERS AND THE TYPE OF MANAGEMENT SYSTEM USED

\begin{tabular}{|l|l|l|l|}
\hline \multicolumn{1}{|c|}{ Variables } & \multicolumn{1}{|c|}{ Coefficient } & Standard error & $\mathrm{P}>/ \mathrm{z} /$ \\
\hline Fixed cost & -0.0000248 & 0.0000144 & $0.085^{*}$ \\
\hline Operating cost & $7.34 \mathrm{Q}-06$ & $3.49 \mathrm{Q}-06$ & $0.036^{* *}$ \\
\hline Generated revenue & $-2.41 \mathrm{Q}-06$ & 0.0000112 & 0.0829 \\
\hline Yield & 0.0002998 & 0.0033474 & 0.929 \\
\hline Price & -0.011619 & 0.0096896 & 0.230 \\
\hline _cons & 3.680801 & 2.928717 & 0.209 \\
\hline $\begin{array}{l}\text { Numbers of Observation = 120, LR chi2 }=9.76, \text { Prob> chi2 }=0.0824 \\
\text { Log likelihood }=-78.299153, \text { Pseudo R2 }=0.0587, * \text { significant at 10\%, **significant at 5\% }\end{array}$ \\
\hline
\end{tabular}

TABLE 4: BUDGETARY TECHNIQUES ANALYSIS OF OWNER MANAGED SYSTEM AND THE LEASED MANAGED SYSTEM OF COCOA PRODUCTION

\begin{tabular}{|l|l|l|}
\hline VARIABLES & OWNER MANAGED & LEASED MANAGED \\
\hline Variable Cost (VC) & $\mathrm{N} 72,442.50$ & $\mathrm{~N} 84,951.95$ \\
\hline Fixed Cost (FC) & $\mathrm{N} 21,315.00$ & $\mathrm{~N} 18,650.00$ \\
\hline Total Revenue (TR) & $\mathrm{N} 205,333.30$ & $\mathrm{~N} 191,485.30$ \\
\hline Total Cost (TC) & $\mathrm{N} 93,757.50$ & $\mathrm{~N} 103,601.95$ \\
\hline Net Farm Income (NFI) & $\mathrm{N} 51,127.50$ & $\mathrm{~N} 66,301.95$ \\
\hline Gross Margin (GM) & $\mathrm{N} 132,890.80$ & $\mathrm{~N} 106,533.35$ \\
\hline Economic Efficiency/ Rate of Return (ROR) & 0.55 & 0.63 \\
\hline Benefit Cost Ratio (B/C Ratio) & 2.19 & 1.85 \\
\hline
\end{tabular}


\begin{tabular}{|l|l|l}
\hline Gross Ratio (GR) & 0.46 & 0.54 \\
\hline
\end{tabular}

\section{CONCLUSION}

\section{Recommendation And Conclusion}

The study summarises that the high benefit relating to cost involved in cocoa production irrespective of the management system and investment in cocoa production can be increased tremendously by providing expanded access to cheap and flexible credit and land which have presented a limiting factors in cocoa production based on the descriptive statistical analysis in the study area.

Based on the result of the budgetary analysis, both management system of production are profitable.

\section{RECOMMENDATION}

*Government should provide more incentives and conducive environment for the cocoa farmers.

* Social amenities should be provided so as to make the production and marketing of cocoa more economical.

*The activities of extension worker should be intensified so that improved and modernized management practices and processing techniques would be disseminated.

*Government should make provision for capital to enables the cocoa farmers improve on their practice.

*Marketing board should be streamlined to encourage farmers in cocoa production irrespective of their gender.

\section{Journal Paper}

\section{References}

[1]. Ajibefun, I.A.and Daramola 2003: 'Determinants of Technical and Allocative Efficiency of Micro enterprises: Firm - level Evidence from Nigeria'. Bulletin of African Development Bank 4: 353 - 395.

[2]. Cocoa Research institute of Nigeria (CRIN) (2003): Bulletin of Cocoa Research Institute of Nigeria CRIN, Ibadan Vol.12 (2003).

[3]. Folayan, J. A. Daramola, G. A. and Oguntade A. E (2006): Structure and Performance Evaluation of Cocoa Marketing Institution in South-Western Nigeria: An Economic Analysis. Journal of Food, Agriculture and Environment (2006) 4(2): 123 - 128

[4]. Nkang N.M., Abang S.O., Akpan O.E and Offem J.K (2006): Cointegration and Error Correction Modelling of Agricultural Export Trade in Nigeria.The case of Cocoa.Journal of Agriculture and Social Science, 2006.

[5]. Oladosu, I.O. and Sanusi, W.A (2004): Communication Effectiveness between Cocoa Research Institute of Nigeria (CRIN) and Cocoa farmers in Cocoa Producing Areas of Oyo State. Journal of Rural Research and Information, 1: 77 - 86 (2004). 